\title{
The effect of angiotensin receptor blockers on C-reactive protein and other circulating inflammatory indices in man
}

\author{
Alessandra Del Fiorentino \\ Silvana Cianchetti \\ Alessandro Celi \\ Giulia Dell'Omo \\ Roberto Pedrinelli \\ Dipartimento Cardio Toracico e \\ Vascolare, Università di Pisa, Italy
}

\begin{abstract}
Anti-inflammatory properties may contribute to the pharmacological effects of angiotensin II receptor blockers (ARBs), a leading therapeutic class in the management of hypertension and related cardiovascular and renal diseases. That possibility, supported by consistent evidence from in-vitro and animal studies showing pro-inflammatory properties of angiotensin II, has been evaluated clinically by measuring the effect of ARBs on C-reactive protein and other circulating indices of inflammation (e-selectin, adhesion molecules, interleukin-6, tissue necrosis factor-alpha, monocyte chemoattractant protein-1) of potential clinical relevance, a body of evidence that this paper aims to review.
\end{abstract}

Keywords: renin-angiotensin system, angiotensin II type 1 receptor blockers, vascular inflammation, C-reactive protein, circulating inflammatory markers

\section{Introduction}

The renin-angiotensin system (RAS; Figure 1) is a multi-step peptidergic system by which circulating angiotensinogen, a liver-derived $\alpha$-glycoprotein derived from liver and other sources such as the kidney, adipose tissue and the heart, ${ }^{1}$ is cleaved by renin, the rate limiting step in the biological cascade, to form the decapeptide angiotensin (Ang) I. In turn, AngI is transformed by angiotensin-converting enzyme (ACE), a membrane-bound metalloproteinase expressed in high concentrations on the surface of pulmonary endothelial cells, ${ }^{1}$ into the octapeptide AngII, the final effector of the RAS. The endocrine RAS, as above summarized, works in concert with local RASs, ie, self-contained, functionally autonomous AngII-generating systems in the heart, the nervous system, reproductive organs, and in interaction with other biological systems, eg, endothelins or nitric oxide. ${ }^{2}$

Most of the cardiovascular effects of AngII are mediated by G coupled type 1 receptors (AT1Rs) expressed in the vascular wall and organs such as liver, adrenals, brain, lung, kidney and the heart, that coexist with type 2 receptors mediating vasodilatation, inhibition of cell growth/proliferation and proapoptosis. ${ }^{3}$ (Pro)renin receptors, which accelerate renin catalytic properties, activate circulating prorenin and stimulate AngII-independent intracellular signaling pathways, have recently been identified ${ }^{4}$ whose more thorough understanding will likely unveil additional pathophysiologic facets of the RAS as a whole (Figure 2).

Each step of the biological cascade leading to AngII, the biological effector of the system, can be pharmacologically inhibited by renin inhibitors such as aliskiren, ACE inhibitors (ACEIs) and All AT1R blockers (ARBs) (Figure 2), these latter triggering a compensatory renin rise due to the disruption of the feedback inhibition of renin production. ${ }^{1-4}$ The increase in renin activity stimulates the conversion of Ang I and Ang II, which may limit the efficacy of RAS inhibition ${ }^{3}$ and the increased renin can also activate the prorenin/renin 


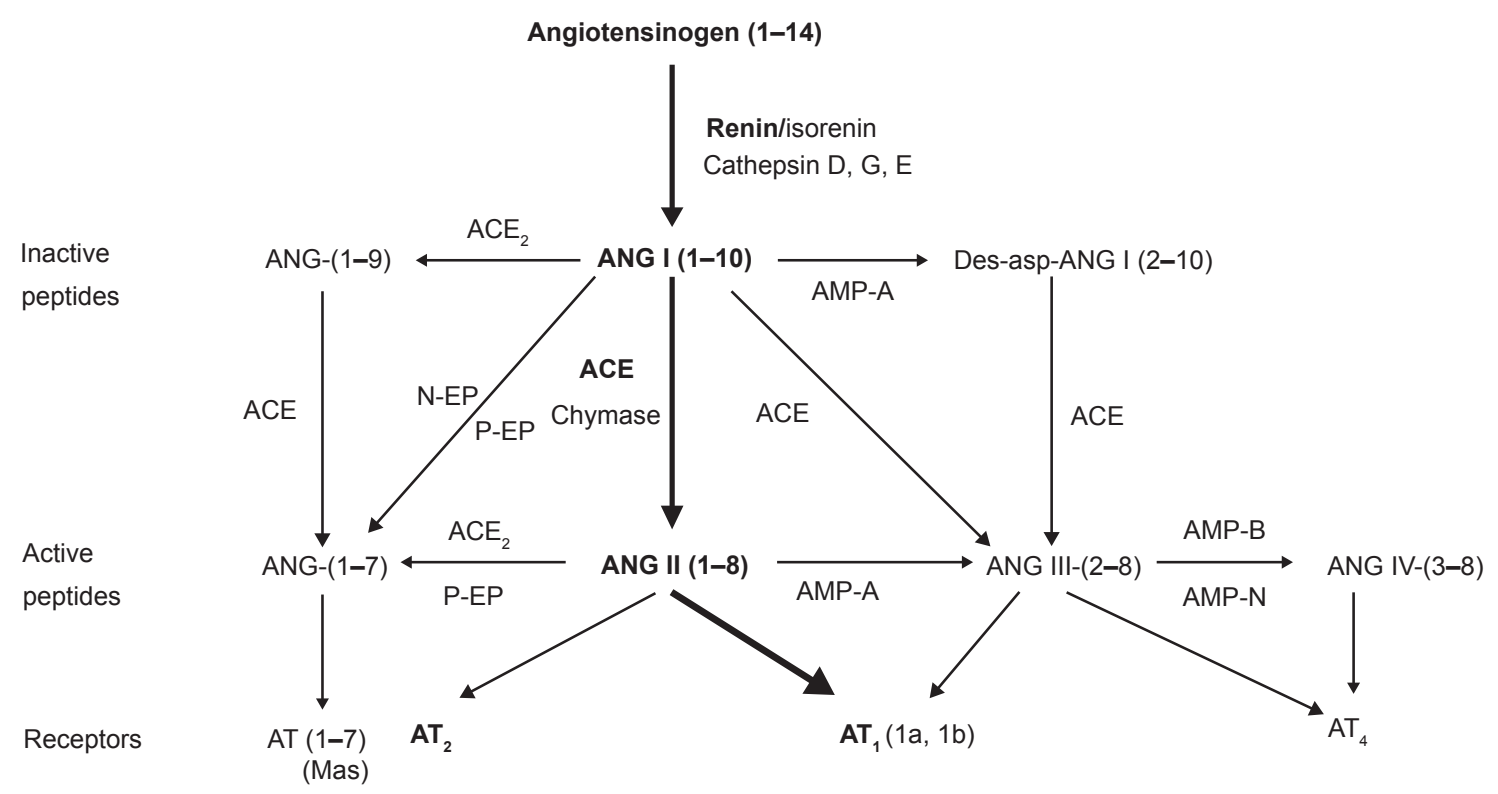

Figure I The renin-angiotensin system and cascade of bioactive angiotensins.

Abbreviations: ACE 2 , ACE-related carboxypeptidase; AMP-A, aminopeptidase A; AMP-B, aminopeptidase B; AMP-N, aminopeptidase N; N-EP, neutral endopeptidase; P-EP, prolylen-dopeptidase.

receptor causing renal and cardiovascular damages independent of Ang II ${ }^{4}$ (Figure 2). ARBs constitute a heterogeneous pharmacological class (Table 1) sharing AT1R antagonism ${ }^{5,6}$ as a common feature whose clinical profile has been clarified by several published randomized clinical trials ${ }^{7-29}$ (Table 2) in hypertension, cardio-, cerebrovascular disease, diabetes, and others either completed ${ }^{30}$ or on their way to completion ${ }^{31,32}$ will further expand our knowledge on this topic.

Although primarily ascribable to AT1R antagonism of the vascular, neurohormonal and renal effects of blood-borne and locally produced AngII, ${ }^{1,2}$ the therapeutic effect of ARBs may be compounded by "pleiotropic" mechanisms related

\section{Classical thinking of the RAS}

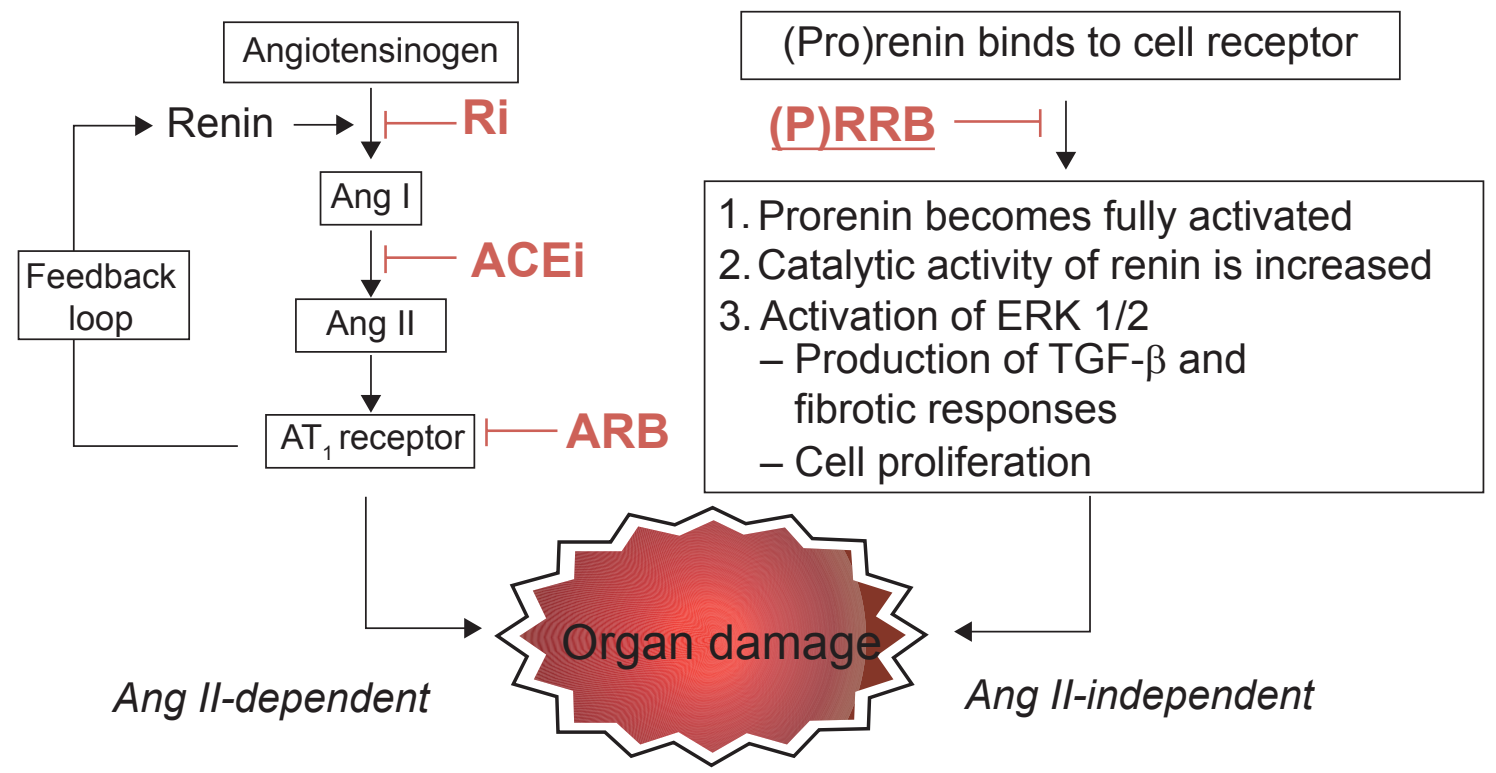

Figure 2 Schematic representation of the classical renin-angiotensin system (RAS) and of the emerging concept integrating the (pro)renin receptor and the blocking of the system at different steps by pharmacological compounds.

Abbreviations: Ri, renin inhibitor; ACEi, angiotensin-converting enzyme inhibitor; ARB, angiotensin receptor blocker; (P)RRB, (pro)renin receptor blocker. ${ }^{4}$ 
Table I Main pharmacokinetic characteristics of the available ARBs

\begin{tabular}{|c|c|c|c|c|c|c|c|}
\hline Drug & $\operatorname{Tmax}_{(\mathrm{h})}$ & $\begin{array}{l}\text { Dose } \\
\text { range (mg) }\end{array}$ & $\begin{array}{l}\text { Bioavailability } \\
\text { (\%) }\end{array}$ & Half-life $_{(\mathrm{h})}$ & Vd (L) & $\begin{array}{l}\text { Elimination } \\
\text { (feces/urine) }\end{array}$ & Antagonism \\
\hline Losartan* & I (3-4) & $50-100$ & 33 & $2(6-9)$ & $34(12)$ & $60 / 35$ & Competitive \\
\hline Valsartan & 2 & $80-160$ & 23 & 6 & 17 & $83 / 13$ & Competitive \\
\hline Irbesartan & $1-2$ & $150-300$ & $60-80$ & $11-15$ & $53-93$ & $80 / 20$ & Insurmountable \\
\hline Candesartan & $3-5$ & $8-32$ & 42 & $9-12$ & 9 & $67 / 33$ & Insurmountable \\
\hline Eprosartan & $2-6$ & $400-800$ & 13 & $5-7$ & 13 & $90 / 10$ & Insurmountable \\
\hline Telmisartan & I & $20-80$ & 43 & 24 & 500 & $98 \%$ fecal & Insurmountable \\
\hline Olmesartan & $1.4-2.8$ & $20-40$ & 26 & 13 & 17 & $35 \%-49 \%$ urine & Insurmountable \\
\hline
\end{tabular}

Abbreviations: ARBs, angiotensin II receptor blockers; Tmax, time to reach peak serum concentration; $\mathrm{Vd}$, distribution volume.

Note: *Values in parentheses refer to EXP3174, the active metabolite of losartan.

to modulation of the multiform effects of AngII on vascular cells (Figure 3) by which the peptide may accelerate the onset and progression of atherosclerotic vascular disease..$^{33}$ Growing evidence, in fact, demonstrates the cytokine-like potential of locally-synthesized AngII to act in a paracrine, autocrine, and possibly intracrine manner to promote vascular inflammation, a main component of the atherogenic process (see below). That interesting possibility, generated by a consistent series of in-vitro and animal studies, has stimulated a number of clinical studies focusing on the effect of ARBs on circulating inflammatory indices ${ }^{34-78}$ that this paper will discuss.

\section{Angll and vascular inflammation}

The classical view of atherosclerosis as a lesion composed by lipid deposits has now been changed to that of a chronic inflammatory disorder triggered and maintained by the production of inflammatory mediators and immune cells involved in the initiation, progression, and rupture of the plaque..$^{79}$ AngII may promote and amplify that process through the congeries of mechanisms summarized in Figure 3. In fact, All facilitates adhesion of monocytes and neutrophils to endothelial cells through AT1R-stimulated upregulation of P-and E-selectin expression, thus capturing free-flowing leukocytes from the blood and allowing endothelial rolling. The peptide also stimulates the expression of intercellular (ICAM-1) and vascular (VCAM-1) cellular adhesion molecules by which leukocytes accumulate at the sites of inflammation and infiltrate the endothelial layer by production of chemokines such as monocyte chemoattractant protein-1 (MCP-1) in endothelial and vascular smooth muscle cells, monocytes/macrophages, and cardiac myocytes. AngII also increases the expression of cytokines such as interleukin-6 (IL-6) that activates macrophages and adhesion molecule expression and increases local angiotensinogen generation and thereby local AngII formation in the vascular wall, further amplifying vascular inflammation. AngII, by stimulating platelet binding to endothelial cells and/or leukocytes, contributes to thrombin release, the main effector of platelets, that augments the expression of P-selectin, E-selectin, VCAM-1, and ICAM-1..$^{79}$ It should, however, be clear that the vascular effects of AngII are complex

Table 2 Acronyms of completed and ongoing randomized controlled clinical trials with ARBs

\begin{tabular}{|c|c|c|c|c|c|c|}
\hline Drug & HT & Stroke & Diabetes/renal & CHF & MI & AF \\
\hline Candesartan & SCOPE $^{15}$ & ACCESS $^{16}$ & $\begin{array}{l}\text { ALPINE }^{19} \\
\text { DIRECT }^{27}\end{array}$ & CHARM $^{17}$ & & \\
\hline Eprosartan & & MOSES $^{22}$ & & & & \\
\hline Irbesartan & & & IDNT $^{8}$, IRMAIII $^{10}$ & I-PRESERVE ${ }^{28}$ & & ACTIVE $^{31}$ \\
\hline Losartan & LIFE' $^{\prime 2}$ & & RENAAL ${ }^{9}$ & ELITE $^{7}, \mathrm{HEAAL}^{32}$ & OPTIMAL ${ }^{14}$ & \\
\hline Olmesartan & & & ROADMAP $^{29}$ & & & \\
\hline Telmisartan & $\begin{array}{l}\text { ONTARGET }{ }^{24} \\
\text { TRANSCEND }{ }^{26}\end{array}$ & PROFESS ${ }^{25}$ & DETAIL ${ }^{21}$ & & & \\
\hline Valsartan & $\begin{array}{l}\text { VALUE }^{20} \\
\text { JIKE| }\end{array}$ & & $\begin{array}{l}\text { MARVAL }{ }^{13} \\
\text { NAVIGATOR }\end{array}$ & VALHEFT"I & VALIANT $^{18}$ & GISSI-AF ${ }^{30}$ \\
\hline
\end{tabular}

Abbreviations: AF, atrial fibrillation; ARBs, angiotensin II receptor blockers; $\mathrm{CHF}$, congestive heart failure; $\mathrm{HT}$, hypertension; MI, myocardial infarction. 


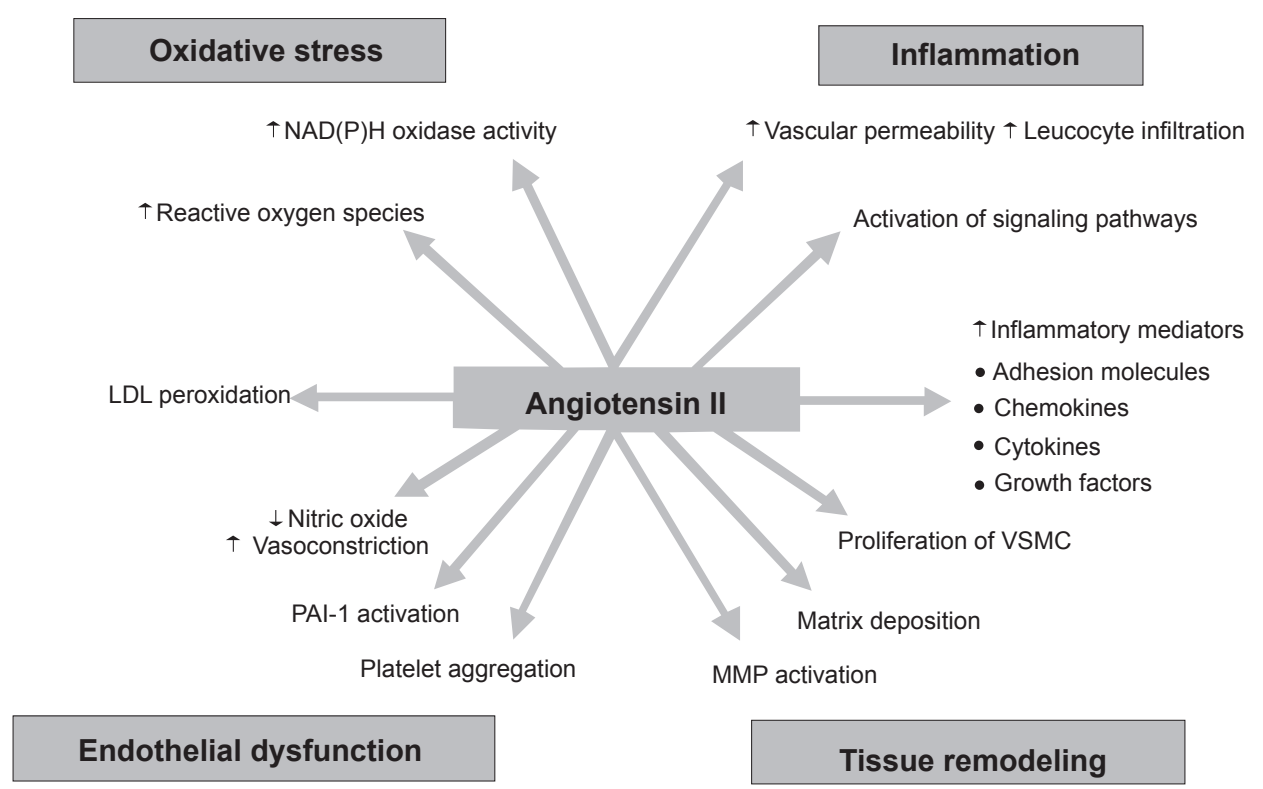

Figure 3 Effects of angiotensin II on vascular cellular biology.

Abbreviations: LDL, low-density lipoprotein; MMP, matrix metallo proteinases; PAI, plasminogen activator inhibitor; VSMC, vascular smooth muscle cells.

and multiform (Figure 3) and involve several intracellular pathways leading to inflammation and proliferation reviewed in detail elsewhere. . $3,79^{-79}$

Ang II directly act on NAD(P)H oxidase, an enzyme present in vascular wall cells consisting of membrane and cytoplasmic subunits and a small GTP-binding protein Rac. ${ }^{81}$ $\mathrm{NAD}(\mathrm{P}) \mathrm{H}$ oxidase generates reactive oxygen species (ROS) that activate nuclear factor kappa B (NFkB), a transcription factor binding specific sequences in the promoter regions of target genes thus inducing transcription of proinflammatory cytokines, chemokines, mediators of inflammation, immune receptors, and adhesion molecules. ${ }^{82}$ The effect of AngII on NFkB has been documented in endothelial and vascular smooth muscle, glomerular, tubular, and mononuclear cells and its overactivation in tissue of ANGII stimulated animals related to AT1R activation. ${ }^{81}$ ROS excess also impairs endothelial function by decreasing NO bioavailability by both constitutive (eNOS) and inducible (iNOS) NO synthases, accelerates atherogenesis ${ }^{83}$ and attenuates BP raise in response to AngII infusion, ${ }^{84,85}$ a piece of evidence suggestive of a role of inflammatory components in the genesis of essential hypertension.

\section{The effect of ARBs on circulating inflammatory indices ARBs and C-reactive protein}

$\mathrm{C}$-reactive protein (CRP) is a protein synthesized by hepatocytes under the influence of IL-6 within 24-72 hrs after infectious and noninfectious disorders, including myocardial infarction and other acute coronary syndromes. Detection of both CRP mRNA and protein in vascular smooth muscle cells and macrophages within atherosclerotic plaques suggests its de novo synthesis in the vessel wall in which CRP may activate the complement system and/or interact with macrophages and other resident vascular cells. ${ }^{86}$ Due to its long-term stability during storage, long half-life, lack of diurnal variation as well as lack of age and sex dependence, circulating CRP represents a reliable long-term index of subclinical inflammation provided of predictive power for cardiovascular events in patients with both established coronary artery disease and in primary prevention independent of concomitant factors such as smoking status, diabetes, blood pressure, use of hormone-replacement therapy and low-density lipoprotein (LDL) cholesterol. ${ }^{87}$

Because of those favorable characteristics for risk stratification, several studies listed in Table 3 have addressed the effect of ARBs on circulating CRP levels in hypertensive and diabetic patients. The Val-MARC (Valsartan-Managing blood pressure Aggressively and evaluating Reductions in hsCRP) study is probably the more important trial addressing the issue of whether BP reduction per se lowers CRP levels, or whether selective AT1R antagonism through valsartan may have independent effects to reduce CRP levels. ${ }^{69}$ The study included 1668 patients with stage 2 hypertension randomly allocated to either valsartan alone (160-320 mg/day, $\mathrm{n}=836$ ) or valsartan/ hydrochlorothiazide (HCTZ, 160-320 mg/12.5 mg/day, $\mathrm{n}=832$ ) for a period of six weeks. At the end of treatment, valsartan 
Table 3 Percent changes in high sensitivity (hs) C-reactive protein (CRP) during ARB treatment

\begin{tabular}{|c|c|c|c|c|c|}
\hline Author & Type of ARB & $\begin{array}{l}\text { Dose and duration } \\
\text { of treatment }\end{array}$ & $\begin{array}{l}\text { Clinical condition } \\
\text { (n. patients) }\end{array}$ & $\begin{array}{l}\text { Hs-CRP baseline } \\
\text { (mg/L) }\end{array}$ & $\%$ Change \\
\hline Wassmann ${ }^{42}$ & C & $16 \mathrm{mg} \times 6 \mathrm{wk}$ & $\mathrm{HC}(\mathrm{I})$ & $7.6 \pm 2.7$ & $-24 \%^{\text {ns }}$ vs $P$ \\
\hline Dohi $^{46}$ & $\mathrm{C}$ & $8 \mathrm{mg} \times 3 \mathrm{mo}$ & HT (67) & $0.7 \pm 0.4$ & $-14 \% *$ vs B \\
\hline $\mathrm{Koh}^{47}$ & C & $16 \mathrm{mg} \times 3 \mathrm{mo}$ & HT (45) & $1.7(0.11-2.6)$ & NS vs B \\
\hline Rosei $^{60}$ & $\mathrm{C}$ & $8-16 \mathrm{mg} \times 3 \mathrm{mo}$ & HT (6I) & $3.1 \pm 2.75$ & $+5 \%$ ns vs B \\
\hline Schram ${ }^{63}$ & C & $8 \mathrm{mg} \times 6-12 \mathrm{mo}$ & HT + D (24) & $1.97(1.14-3.65)$ & NS vs B \\
\hline White ${ }^{75}$ & $\mathrm{C}$ & $4-32 \mathrm{mg} \times 6 \mathrm{mo}$ & $\mathrm{CHF}(4 \mathrm{I})$ & $7 \mathrm{mg} / \mathrm{L}$ & $-26 \% *$ vs $P$ \\
\hline Schieffer ${ }^{54}$ & I & $300 \mathrm{mg} \times 3 \mathrm{mo}$ & $\mathrm{CAD} / \mathrm{HT}(2 \mathrm{I})$ & NR & $-2.5 \mathrm{mg} / \mathrm{L} *$ vs $B$ \\
\hline Biasucci $^{57}$ & 1 & $300 \mathrm{mg} \times \mathrm{I} \mathrm{mo}$ & CAD (I3) & $3.1(0.7-17.7)$ & $-6 \mid \% *$ vs P \\
\hline Andersen $^{34}$ & L & $50-100 \mathrm{mg} \times 2 \mathrm{mo}$ & Type ID (I6) & $1.0(0.5-1.82)$ & $+16 \%{ }^{\text {ns }}$ vs $P$ \\
\hline Prasad $^{38}$ & L & $25-50 \mathrm{mg} \times 2 \mathrm{mo}$ & CAD (3I) & $4.5 \pm 1.1$ & $+10 \%^{\text {ns }}$ vs B \\
\hline $\mathrm{Koh}^{52}$ & L & $100 \mathrm{mg} \times 2 \mathrm{mo}$ & $\mathrm{HT} / \mathrm{HC}(47)$ & $0.85(0.3-1.3)$ & $+6 \%{ }^{\text {ns }}$ vs B \\
\hline Fliser $^{50}$ & O & $20 \mathrm{mg} \times 3 \mathrm{mo}$ & HT/MS (I00) & $3.56 \pm 3.17$ & $-15 \% *$ vs $B$ \\
\hline Miura $^{59}$ & $\mathrm{~T}$ & $40 \mathrm{mg} \times 3 \mathrm{mo}$ & Type 2D (I8) & $1.54 \pm 1.55$ & $-29 \% *$ vs B \\
\hline Koulouris ${ }^{62}$ & $\mathrm{~T}$ & $40 \mathrm{mg} \times 3 \mathrm{mo}$ & Type2D (37) & $1.38 \pm 1.0$ & $-38 \% *$ vs P \\
\hline $\operatorname{Link}^{65}$ & $\mathrm{~T}$ & $40 \mathrm{mg} \times 3 \mathrm{mo}$ & CAD/HT (2I) & $2.5 \pm 0.6$ & $-44 \% *$ vs B \\
\hline Nagel $^{66}$ & $\mathrm{~T}$ & $40 \mathrm{mg} \times 3 \mathrm{mo}$ & HT/MS (20) & $5.3 \pm 3.77$ & $+8 \%{ }^{\text {ns }}$ vs B \\
\hline Yano $^{74}$ & $\mathrm{~T}$ & $40 \mathrm{mg} \times 3 \mathrm{mo}$ & HT/MS (30) & 0.77 & $-22 \% *$ vs B \\
\hline Galle $^{77}$ & $\mathrm{~T}$ & $40-80 \mathrm{mg} \times \mathrm{I} \mathrm{yr}$ & Type2D + HT (255) & $2.1(0.28-15.8)$ & $-3 \%^{\text {ns }}$ vs $B$ \\
\hline Nakayama $^{78}$ & $\mathrm{~T}$ & $40 \mathrm{mg} / 2 \mathrm{mo}$ & HT/DIAB (20) & $0.76 \pm 0.6$ & $+90 \%$ vs $B$ \\
\hline Dandona $^{45}$ & $\mathrm{~V}$ & $160 \mathrm{mg} \times \mathrm{I} w \mathrm{wk}$ & NS (8) & $1.27 \pm 1.54$ & $-23 \% *$ vs B \\
\hline Yasunari $^{55}$ & $\mathrm{~V}$ & $80 \mathrm{mg} \times 8 \mathrm{mo}$ & HT (52) & NR & $-29 \% *$ vs B \\
\hline Anand ${ }^{56}$ & $\mathrm{~V}$ & $160 \mathrm{mg} \times \mathrm{I} \mathrm{yr}$ & CHF (I06) & 3.23 & $-9.3 \% *$ vs B \\
\hline Manabe $^{58}$ & $\mathrm{~V}$ & $40-80 \times 1 \mathrm{mo}$ & HT (29) & $1.5 \pm 1.1$ & $-13 \%^{\text {ns }}$ vs B \\
\hline Ruilope $^{61}$ & $\mathrm{~V}$ & $160 \mathrm{mg} \times 6 \mathrm{mo}$ & HT (720) & NR & $-13 \% *$ vs B \\
\hline Ridker ${ }^{69}$ & $\mathrm{~V}$ & $80-160 \mathrm{mg} \times 6 \mathrm{wk}$ & HT (836) & 2.11 & $-8.9 \% *$ vs $B$ \\
\hline Rajagopalan ${ }^{73}$ & V & $160 \mathrm{mg} \times 4 \mathrm{mo}$ & HT (I07) & 3 & $-5.3 \%^{\text {ns }}$ vs B \\
\hline Galle $^{77}$ & V & $80-160 \mathrm{mg} \times \mathrm{I} \mathrm{yr}$ & DIAB + HT (255) & $1.88(0.28-12.59)$ & $-3 \%^{\text {ns }}$ vs B \\
\hline
\end{tabular}

Abbreviations: C, candesartan; I, irbesartan; L, losartan; O, olmesartan; T, telmisartan; $\mathrm{V}$, valsartan; $\mathrm{CHF}$, congestive heart failure; $\mathrm{HC}$, hypercholesterolemia; $\mathrm{HT}$, hypertension; CAD, coronary artery disease;T2D, type 2 diabetes;TID, type I diabetes; NS, normal subjects; MS, metabolic syndrome; B, baseline; P, concurrent placebo; ns, not significant. Note: *denotes statistical significance ( $\mathrm{p}<0.05$ or less) of changes from either baseline or concurrent placebo.

alone slightly but significantly reduced high sensitivity (hs)CRP levels, an effect maintained over an extended follow-up period albeit with a low level of association with achieved BP. As CRP levels were unchanged in the combined valsartan/HCTZ therapy group, the data were taken as suggestive of a negative interaction of thiazide diuretics with the anti-inflammatory effects of ARBs conclusion. That conclusion contrasts, though, with the results of the VAST (Valsartan/HCTZ versus Amlodipine in STage II hypertensive patients) trial whose primary objective was to determine whether valsartan $160 \mathrm{mg}$ plus HCTZ $25 \mathrm{mg}$ OD would be more effective than monotherapy with amlodipine $10 \mathrm{mg}$ OD. ${ }^{61}$ Modulation by valsartan of CRP levels was confirmed in other, small-sized studies in patients with hypertension, ${ }^{55}$ congestive heart failure ${ }^{56}$ as well as normal subjects ${ }^{45}$ although other reports did not confirm those data. ${ }^{58,73,77}$ For example, Rajagopalan and colleagues ${ }^{73}$ found no significant change in hs-CRP in 104 hypertensive patients randomized to 12 weeks valsartan (160 mg daily) as compared with significant reductions in those on combined statin treatment. Galle and colleagues in the VIVALDI trial (inVestigate the efficacy of telmIsartan versus VALsartan in hypertensive type 2 DIabetic patients with overt nephropathy $)^{77}$ found no influence of valsartan $(160 \mathrm{mg})$ as well as telmisartan $(80 \mathrm{mg})$ on inflammatory parameters in 255 hypertensive patients with diabetic nephropathy and the study was unable to show any effect beyond that due to blood pressure 
control. Nonsignificant changes in hsCRP were reported with candesartan ${ }^{42,47,60,63}$ including the CENTRO (CandEsartaN on aTherosclerotic Risk factors) trial, a multicenter, randomized, double blind comparison of candesartan and enalapril, an ACEI, in hypertensive, diabetic patients showing no effect of the ARB (but also enalapril) on hsCRP.${ }^{60}$ Similar discrepancies also characterized the effect of telmisartan ${ }^{59,62,65,66,74,78}$ including the already commented VIVALDI trial. ${ }^{77}$ Positive results were reported for irbesartan in two studies in coronary heart disease patients, ${ }^{54,57}$ but their small sample size preludes generalization. Olmesartan was tested in a well designed and carefully conducted prospective, placebo-controlled, double-blind multicenter study by Fliser and colleagues ${ }^{50}$ who measured hs-CRP levels and other inflammatory markers in 199 patients with essential hypertension and obesity-related microinflammation. After 12 weeks of therapy, with additional HTCZ if needed, olmesartan decreased hs-CRP $(-21.1 \%$; P $<0.02)$, TNF- $\alpha$ $(-13.6 \%$; P $<0.01)$, IL-6 (-18.0\%; P < 0.01) and MCP-1 $(-6.5 \% ; \mathrm{P}<0.01)$. Albeit gathered in a well designed and carefully conducted study, those results need confirmation in additional trials, however. A greater anti-inflammatory effect of olmesartan as compared with telmisartan was recently claimed by Nakayama and colleagues, ${ }^{78}$ but the conclusion is flawed by the experimental design lacking adequate washout prior to randomization. Notably, losartan did not affect CRP in patients with diabetic nephropathy, ${ }^{34}$ coronary artery disease, ${ }^{38}$ and hypertension. ${ }^{54}$ No data are available about the effect of eprosartan.

\section{ARBs and circulating adhesion molecules, cytokines, and chemokines}

A number of clinical studies have assessed the effect of ARBs on circulating inflammatory markers other than CRP such as E-selectin, a member of the selectin family expressed on the surface of stimulated endothelial cells, and ICAM-1 and VCAM-1, two immunoglobulin-like molecules acting as endothelial ligands to facilitate endothelial adhesion of circulating leukocytes. ${ }^{79}$ Those biological products circulate in blood as a result of enzymatic cleavage or from shedding of damaged or activated endothelial cells under the influence of proatherogenic stimuli such as hypertension, type 2 diabetes, obesity as well as established peripheral and coronary artery disease. ${ }^{79,88}$ While the prognostic power of raised s-eSEL is dubious, ${ }^{88}$ circulating ICAM-1 predicted cardiovascular risk independent of traditional risk factors in the 14,916 healthy men enrolled in the Physicians' Health Study (PHS), ${ }^{89}$ as well as in the elderly, apparently healthy subjects of the Atherosclerosis Risk in Communities (ARIC) study. ${ }^{90}$ On the other hand, VCAM-1 did not predict future cardiovascular risk, ${ }^{90}$ suggesting important distinctions between the roles of different CAMs in atherogenesis. Evidence has also been gathered in support of the clinical relevance of inflammatory cytokines such as circulating IL-6 and TNF- $\alpha$, and MCP-1, a chemokine that orchestrates the migration of leukocytes into the intima and within atherosclerotic lesions. ${ }^{79}$ Increased plasma IL-6 levels were reported early after admission for acute coronary syndromes and associated with a complicated in-hospital course and higher IL-6 levels predicted acute coronary syndromes in apparently healthy men. ${ }^{91}$ Post-MI elevations of circulating TNF- $\alpha^{92}$ and MCP- $1^{93}$ also associated with an increased risk of recurrent coronary events. ${ }^{89}$

As summarized in Table 4, losartan did not affect circulating adhesion molecules in patients with diabetes and/or hypertension and/or coronary artery disease ${ }^{34,38,39,53}$ while a significant decrease was reported only in two, small studies in normal subjects. ${ }^{41,51}$ The effect of the drug on eSEL, on the other hand, was consistently negative..$^{34,38,39,41,51}$ The same discrepant behavior was shared by candesartan, ${ }^{35,42,60}$ the other ARBs frequently used in studies of this kind, while either eprosartan ${ }^{40}$ or telmisartan ${ }^{65}$ treatment did not change VCAM-1 levels to a statistically significant extent. No data are available for irbesartan or olmesartan.

As shown in Table 4, similar considerations hold for the effect of ARBs on MCP-1, TNF- $\alpha$ and IL-6. ${ }^{42,47,75}$

\section{Conclusions}

Despite a quite consistent evidence from basic research field, the anti-inflammatory effect of ARBs in man, at least to the extent derived from their effect on circulating inflammatory indices, is quite inconsistent, a conclusion that applies even to studies apparently adopting the same drug at similar dosages, comparable patient selection criteria and experimental design. Further limitations derive from the small sample sizes that characterize many of the available studies, heterogeneity of ARBs as a pharmacological class (see Table 1), lack of prospective studies evaluating the relationship between anti-inflammatory effects of ARBs and incident morbid events and the complexity of the effects of AngII on vascular biology (Figure 3). Additional difficulties derive from the inherent variability of circulating inflammatory indices, a pattern emerging quite clearly from Table 3 to which genetic factors acting at the individual ${ }^{94}$ as well as the population ${ }^{95}$ level may contribute. Not unlike ARBs, ACEIs showed divergent results, ${ }^{96}$ sometimes in contrast with the effects of the ARBs. Thus, enalapril but not losartan reduced inflammatory markers in hypertensive and diabetic patients. ${ }^{39}$ 
Table 4 Percent changes in circulating e-selectin (SEL), intercellular cellular adhesion molecule (ICAM)-I, vascular cellular adhesion molecule (VCAM)-I, interleukin-6 (IL-6), tumor necrosis factor (TNF)- $\alpha$, monocyte chemoattractant protein (MCP)-I during ARB treatment

\begin{tabular}{|c|c|c|c|c|c|c|c|c|}
\hline Author & Type of ARB & $\begin{array}{l}\text { Clinical condition } \\
\text { (n. patients) }\end{array}$ & e-SEL & SICAM-I & sVCAM-I & IL-6 & TNF- $\alpha$ & MCP-I \\
\hline Tsutamoto ${ }^{35}$ & $\mathrm{C}$ & $\mathrm{CHF}(14)$ & $\mathrm{N} / \mathrm{A}$ & $\downarrow$ & $\downarrow$ & $\downarrow$ & $\downarrow$ & $\mathrm{N} / \mathrm{A}$ \\
\hline Wassmann ${ }^{42}$ & C & $\mathrm{HC}(17)$ & $\mathrm{N} / \mathrm{A}$ & $-22.6 \% *$ & $\mathrm{~N} / \mathrm{A}$ & $N / A$ & $+6.8 \%$ ns & $-18.1 \% *$ \\
\hline Koh $^{47}$ & C & HT (47) & $\mathrm{N} / \mathrm{A}$ & N/A & $\mathrm{N} / \mathrm{A}$ & $N / A$ & $-24 \% *$ & $-7 \% *$ \\
\hline Rosei $^{60}$ & C & $\mathrm{HT}(6 \mathrm{I})$ & $-5 \% *$ & $-4.1 \% *$ & N/A & $\mathrm{N} / \mathrm{A}$ & N/A & N/A \\
\hline Schram ${ }^{63}$ & C & HT (22) & $N / A$ & ns & $\downarrow$ & $N / A$ & N/A & $N / A$ \\
\hline Ogawa ${ }^{68}$ & $\mathrm{C} / \mathrm{V}$ & HT/T2D (33) & $\mathrm{N} / \mathrm{A}$ & $\mathrm{N} / \mathrm{A}$ & $\mathrm{N} / \mathrm{A}$ & $-29.4 \%$ & N/A & $-25.7 \%$ \\
\hline White ${ }^{75}$ & C & $\mathrm{CHF}(4 \mathrm{I})$ & ns & ns & N/A & ns & N/A & Ns \\
\hline Rahman $^{40}$ & $\mathrm{E}$ & HT (19) & N/A & $\mathrm{N} / \mathrm{A}$ & $-35 \%$ & $\mathrm{~N} / \mathrm{A}$ & N/A & $-34 \% *$ \\
\hline Lauten ${ }^{48}$ & I & CAD (37) & $N / A$ & $\mathrm{~N} / \mathrm{A}$ & $\mathrm{N} / \mathrm{A}$ & $\downarrow$ & N/A & $\mathrm{N} / \mathrm{A}$ \\
\hline Schieffer ${ }^{54}$ & I & CAD/HT (2I) & $N / A$ & $\mathrm{~N} / \mathrm{A}$ & $N / A$ & $\downarrow$ & $N / A$ & $N / A$ \\
\hline De Rosa ${ }^{64}$ & $\mathrm{I} / \mathrm{T}$ & T2D/MS (I88) & $N / A$ & $N / A$ & $N / A$ & $\downarrow$ & $N / A$ & $N / A$ \\
\hline Andersen ${ }^{34}$ & $\mathrm{~L}$ & TID (29) & $-1 \%$ ns & $+2 \%$ ns & $-5 \% *$ & $\mathrm{~N} / \mathrm{A}$ & N/A & $\mathrm{N} / \mathrm{A}$ \\
\hline Prasad $^{38}$ & L & CAD (3I) & $+2 \%$ ns & $+5 \%$ ns & $+3 \%$ ns & $\mathrm{N} / \mathrm{A}$ & $\mathrm{N} / \mathrm{A}$ & $\mathrm{N} / \mathrm{A}$ \\
\hline Jilma ${ }^{39}$ & L & HT (I5) & $-3 \%$ ns & $-5 \%$ ns & $-8 \%^{\mathrm{ns}}$ & $\mathrm{N} / \mathrm{A}$ & $+1 \%^{\mathrm{ns}}$ & $+2 \%^{\text {ns }}$ \\
\hline Rajagopalan ${ }^{41}$ & L & NS (18) & ns & $-50 \% *$ & $-24 \% *$ & N/A & N/A & $-30 \% *$ \\
\hline Graninger $^{51}$ & L & NS (7) & $0 \%{ }^{\text {ns }}$ & $-11 \% *$ & $-11 \% *$ & N/A & $N / A$ & $N / A$ \\
\hline Koh $^{52}$ & L & HT (47) & $N / A$ & $\mathrm{~N} / \mathrm{A}$ & $\mathrm{N} / \mathrm{A}$ & $N / A$ & $N / A$ & $-7 \% *$ \\
\hline Sardo ${ }^{53}$ & $\mathrm{~L}$ & HT (20) & $N / A$ & $-3 \%$ ns & $N / A$ & $\mathrm{~N} / \mathrm{A}$ & $-8 \%^{\mathrm{ns}}$ & N/A \\
\hline Fliser ${ }^{50}$ & $\circ$ & HT (100) & $N / A$ & $N / A$ & $\mathrm{~N} / \mathrm{A}$ & $-18 \% *$ & $-14 \% *$ & $-4 \% *$ \\
\hline $\operatorname{Link}^{65}$ & $\mathrm{~T}$ & HT (2I) & $\mathrm{N} / \mathrm{A}$ & $\mathrm{N} / \mathrm{A}$ & $-14 \%^{\mathrm{ns}}$ & $-38 \%^{\mathrm{ns}}$ & $-39 \%^{\mathrm{ns}}$ & $\mathrm{N} / \mathrm{A}$ \\
\hline Nagel ${ }^{66}$ & $\mathrm{~T}$ & HT/MS (20) & $N / A$ & $\mathrm{~N} / \mathrm{A}$ & $\mathrm{N} / \mathrm{A}$ & $-8 \%^{\mathrm{ns}}$ & $\mathrm{N} / \mathrm{A}$ & $\mathrm{N} / \mathrm{A}$ \\
\hline Manabe $^{58}$ & V & HT (39) & $\mathrm{N} / \mathrm{A}$ & $N / A$ & $N / A$ & $-4 \% *$ & $-33 \% *$ & $N / A$ \\
\hline Nomura $^{67}$ & V & HT/DIAB (28) & $-6.1 \% *$ & $-3.6 \%$ & $N / A$ & N/A & $-6.6 \% *$ & $-4.7 \% *$ \\
\hline Rajagopalan $^{73}$ & V & HT (I07) & $\mathrm{N} / \mathrm{A}$ & $\mathrm{N} / \mathrm{A}$ & $\mathrm{N} / \mathrm{A}$ & $\mathrm{N} / \mathrm{A}$ & $\mathrm{N} / \mathrm{A}$ & $-15.6 \% *$ \\
\hline
\end{tabular}

Abbreviations: C, candesartan; I, irbesartan; L, losartan; O, olmesartan; T, telmisartan; $\mathrm{V}$, valsartan; CHF, congestive heart failure; HC, hypercholesterolemia; $\mathrm{HT}$, hypertension; CAD, coronary artery disease;T2D, type 2 diabetes; TID, type I diabetes; NS, normal subjects; MS, metabolic syndrome; B, baseline; P, concurrent placebo; ns, not significant; N/A, not assessed.

Notes: $\downarrow$ Indicates significant reductions in absence of precise figures retrievable from the publication. *Denotes statistical significance $(\mathrm{p}<0.05$ or less).

It should also be noted that interference on inflammatory indices is not specific for RAS inhibitors since other classes of cardiovascular drugs such as beta-adrenoceptor blocking drugs, ${ }^{97,98}$ statins $^{99}$ as well as nonpharmacological interventions such as exercise training, weight loss ${ }^{94}$ and nutritional factors ${ }^{100}$ may influence CRP levels. Suggestions have also been raised about a beneficial effect of intensive blood pressure and lipid treatment per se. ${ }^{101}$ Moreover, the validity of circulating inflammatory markers as a surrogate end-point for an underlying inflammatory process is unclear since the relationship with their activity at the local level is unknown. Importantly, modifications in circulating CRP, even when highly consistent such as in the case of statins, ${ }^{99}$ have dubious pathophysiological significance since decrements in hsCRP were associated with either no change, ${ }^{102,103}$ or improved cardiovascular prognosis. ${ }^{104}$ As a matter of fact, the LDL- and
CRP-lowering effect of statins ${ }^{99,105}$ are closely intertwined, possibly as an expression of their metabolic effect on the liver. For these reasons, no firm conclusions can be drawn about their effect at this point and further studies are needed.

\section{Disclosure}

The authors report no conflicts of interest in this work.

\section{References}

1. Inagami T. A memorial to Robert Tiegerstedt: the centennial of renin discovery. Hypertension. 1998;32(6):953-957.

2. Paul M, Poyan Mehr A, Kreutz R. Physiology of local renin-angiotensin systems. Physiol Rev. 2006;86(3):747-803.

3. de Gasparo M, Catt KJ, Inagami T, Wright JW, Unger T. International union of pharmacology. XXIII. The angiotensin II receptors. Pharmacol Rev. 2000;52(3):415-472.

4. Nguyen G, Contrepas A. The (pro)renin receptors. J Mol Med. 2008;86(6):643-646. 
5. Israili ZH. Clinical pharmacokinetics of angiotensin II (AT1) receptor blockers in hypertension. J Hum Hypertens. 2000;14(Supp1 1): S73-S86.

6. Song JC, White CM. Pharmacologic, pharmacokinetic, and therapeutic differences among angiotensin II receptor antagonists. Pharmacotherapy. 2000;20:130-139.

7. Pitt B, Poole-Wilson PA, Segal R; for the Losartan Heart Failure Survival Study ELITE II. Effect of losartan compared with captopril on mortality in patients with symptomatic heart failure: randomised trial--the Losartan Heart Failure Survival Study ELITE II. Lancet. 2000;355(9215):1582-1587.

8. Lewis EJ, Hunsicker LG, Clarke WR; for the Collaborative Study Group. Renoprotective effect of the angiotensin-receptor antagonist irbesartan in patients with nephropathy due to type 2 diabetes. $N$ Engl $J$ Med. 2001;345(12):851-860.

9. Brenner BM, Cooper ME, de Zeeuw D; for the RENAAL Study Investigators: Effects of losartan on renal and cardiovascular outcomes in patients with type 2 diabetes and nephropathy. $N$ Engl $J$ Med. 2001;345(12):861-869.

10. Parving HH, Lehnert $\mathrm{H}$, Brochner-Mortensen J; for the Irbesartan in Patients with Type 2 Diabetes and Microalbuminuria Study Group: The effect of irbesartan on the development of diabetic nephropathy in patients with type 2 diabetes. N Engl J Med. 201;345(12):870-878.

11. Cohn JN, Tognoni G; for the Valsartan Heart Failure Trial Investigators. A randomized trial of the angiotensin-receptor blocker valsartan in chronic heart failure. $N$ Engl J Med. 2001;345(23):1667-1675.

12. Dahlöf B, Devereux RB, Kjeldsen SE; for the LIFE Study Group. Cardiovascular morbidity and mortality in the Losartan Intervention For Endpoint reduction in hypertension study (LIFE): a randomised trial against atenolol. Lancet. 2002;359(9311):995-1003.

13. Viberti G, Wheeldon NM; for the Microalbuminuria Reduction with Valsartan (MARVAL) Study Investigators. Microalbuminuria reduction with valsartan in patients with type 2 diabetes mellitus. Circulation. 2002;106(6):672-678.

14. Dickstein K, Kjekshus J; for the OPTIMAAL Study Group. Effects of losartan and captopril on mortality and morbidity in high-risk patients after acute myocardial infarction: the OPTIMAAL randomised trial. Optimal Trial in Myocardial Infarction with Angiotensin II Antagonist Losartan. Lancet. 2002;360(9335):752-760.

15. Lithell H, Hansson L, Skoog I; for the SCOPE Study Group. The Study on Cognition and Prognosis in the Elderly (SCOPE): principal results of a randomized double-blind intervention trial. J Hypertens. 2003;21(5):875-886.

16. Schrader J, Lüders S, Kulschewski A; for the Acute Candesartan Cilexetil Therapy in Stroke Survivors Study Group. The ACCESS Study: evaluation of Acute Candesartan Cilexetil Therapy in Stroke Survivors. Stroke. 2003;34(7):1699-1703.

17. Yusuf S, Pfeffer MA, Swedberg K; for the CHARM Investigators and Committees. Effects of candesartan in patients with chronic heart failure and preserved left-ventricular ejection fraction: the CHARM-Preserved Trial. Lancet. 2003;362(9386):777-781.

18. Pfeffer MA, McMurray JJ, Velazquez EJ, et al. Valsartan, captopril, or both in myocardial infarction complicated by heart failure, left ventricular dysfunction, or both. N Engl J Med. 2003;(20)349:1893-1906.

19. Lindholm LH, Persson M, Alaupovic P, Carlberg B, Svensson A, Samuelsson O. Metabolic outcome during 1 year in newly detected hypertensives: results of the Antihypertensive Treatment and Lipid Profile in a North of Sweden Efficacy Evaluation (ALPINE study). J Hypertens. 2003;21(8):1563-1574.

20. Julius S, Kjeldsen SE, Weber M; for the VALUE trial group. Outcomes in hypertensive patients at high cardiovascular risk treated with regimens based on valsartan or amlodipine: the VALUE randomised trial. Lancet. 2004;363(9426):2022-2031.

21. Barnett AH, Bain SC, Bouter P; for the Diabetics Exposed to Telmisartan and Enalapril Study Group. Angiotensin-receptor blockade versus converting-enzyme inhibition in type 2 diabetes and nephropathy. N Engl J Med. 2004;351(19):1952-1961.
22. Schrader J, Lüders S, Kulschewski A; for the MOSES Study Group. Morbidity and Mortality After Stroke, Eprosartan Compared with Nitrendipine for Secondary Prevention: principal results of a prospective randomized controlled study (MOSES). Stroke. 2005;36(6):1218-1226.

23. Mochizuki S, Dahlöf B, Shimizu M; for the Jikei Heart Study group. Valsartan in a Japanese population with hypertension and other cardiovascular disease (Jikei Heart Study): a randomised, open-label, blinded endpoint morbidity-mortality study. Lancet. 2007;369(9571):1431-1439.

24. ONTARGET Investigators, Yusuf S, Teo KK, et al. Telmisartan, ramipril, or both in patients at high risk for vascular events. $N$ Engl $J$ Med. 2008;358(15):1547-1559.

25. Yusuf S, Diener HC, Sacco RL; for the PRoFESS Study Group. Telmisartan to prevent recurrent stroke and cardiovascular events. $N$ Engl J Med. 2008;359(12):1225-1237.

26. Telmisartan Randomised AssessmeNt Study in ACE iNtolerant subjects with cardiovascular Disease (TRANSCEND) Investigators, Yusuf S, Teo K, et al. Effects of the angiotensin-receptor blocker telmisartan on cardiovascular events in high-risk patients intolerant to angiotensinconverting enzyme inhibitors: a randomised controlled trial. Lancet. 2008;372(9644):1174-1183.

27. Sjølie AK, Klein R, Porta M; for the DIRECT Programme Study Group. Effect of candesartan on progression and regression of retinopathy in type 2 diabetes (DIRECT-Protect 2): a randomised placebo-controlled trial. Lancet. 2008;372(9645):1394-1402.

28. Massie BM, Carson PE, McMurray JJ; for the I-PRESERVE Investigators. Irbesartan in Patients with Heart Failure and Preserved Ejection Fraction. N Engl J Med. 2008;359(23):2456-2467.

29. Haller H, Viberti GC, Mimran A, et al. Preventing microalbuminuria in patients with diabetes: rationale and design of the Randomised Olmesartan and Diabetes Microalbuminuria Prevention (ROADMAP) study. J Hypertens. 2006;24(2):403-408.

30. Disertori M, Latini R, Maggioni AP; for the GISSI-AF Investigators. Rationale and design of the GISSI-Atrial Fibrillation Trial: a randomized, prospective, multicentre study on the use of valsartan, an angiotensin II AT1-receptor blocker, in the prevention of atrial fibrillation recurrence. J Cardiovasc Med (Hagerstown). 2006;7(1):29-38.

31. Connolly S, Yusuf S, Budaj A et al; for the ACTIVE Investigators. Rationale and design of ACTIVE: the atrial fibrillation clopidogrel trial with irbesartan for prevention of vascular events. Am Heart J. 2006;151(6):1187-1193.

32. Konstam MA, Poole-Wilson PA, Dickstein K, Drexler H, Justice SJ, Komajda $\mathrm{M}$ et al. Design of the heart failure endpoint evaluation of AII-antagonist losartan (HEAAL) study in patients intolerant to ACE-inhibitor. Eur J Heart Fail. 2008;10(9):899-906.

33. Hunyady L, Catt KJ. Pleiotropic AT1 receptor signaling pathways mediating physiological and pathogenic actions of angiotensin II. Mol Endocrinol. 2006;20(5):953-970.

34. Andersen S, Schalkwijk CG, Stehouwer CD, Parving HH. Angiotensin II blockade is associated with decreased plasma leukocyte adhesion molecule levels in diabetic nephropathy. Diabetes Care. 2000;23(7): 1031-1032.

35. Tsutamoto T, Wada A, Maeda K, et al. Angiotensin II type 1 receptor antagonist decreases plasma levels of tumor necrosis factor alpha, interleukin- 6 and soluble adhesion molecules in patients with chronic heart failure. J Am Coll Cardiol. 2000;35(3):714-721.

36. Khan BV, Navalkar S, Khan QA, Rahman ST, Parthasarathy S. Irbesartan, an angiotensin type 1 receptor inhibitor, regulates the vascular oxidative state in patients with coronary artery disease. $J$ Am Coll Cardiol. 2001;38(6):1662-1667.

37. Navalkar S, Parthasarathy S, Santanam N, Khan BV. Irbesartan, an angiotensin type 1 receptor inhibitor, regulates markers of inflammation in patients with premature atherosclerosis. $J$ Am Coll Cardiol. 2001;37(2):440-444.

38. Prasad A, Koh KK, Schenke WH, et al. Role of angiotensin II type 1 receptor in the regulation of cellular adhesion molecules in atherosclerosis. Am Heart J. 2001;142(2):248-253. 
39. Jilma B, Li-Saw-Hee FL, Wagner OF, Beevers DG, Lip GY. Effects of enalapril and losartan on circulating adhesion molecules and monocyte chemotactic protein-1. Clin Sci. 2002;103(2):131-136.

40. Rahman ST, Lauten WB, Khan QA, Navalkar S, Parthasarathy S, Khan BV. Effects of eprosartan versus hydrochlorothiazide on markers of vascular oxidation and inflammation and blood pressure (reninangiotensin system antagonists, oxidation, and inflammation). $\mathrm{Am} \mathrm{J}$ Cardiol. 2002;89(6):686-690.

41. Rajagopalan S, Brook R, Mehta RH, et al. Effect of losartan in aging related endothelial impairment. Am J Cardiol. 2002;89(5):562-566.

42. Wassmann S, Hilgers S, Laufs U, Bohm M, Nickenig G. Angiotensin II type 1 receptor antagonism improves hypercholesterolemia-associated endothelial dysfunction. Arterioscler Thromb Vasc Biol. 2002;22(7): 1208-1212.

43. Agarwal R. Proinflammatory effects of oxidative stress in chronic kidney disease: role of additional angiotensin II blockade. Am J Physiol (Renal Physiol). 2003;284(4):F863-F869.

44. Baykal Y, Yilmaz MI, Celik T et al. Effects of antihypertensive agents, alpha receptor blockers, beta blockers, angiotensin-converting enzyme inhibitors, angiotensin receptor blockers and calcium channel blockers, on oxidative stress. J Hypertens. 2003;21(6):1207-1211.

45. Dandona P, Kumar V, Aljada A, et al. Angiotensin II receptor blocker valsartan suppresses reactive oxygen species generation in leukocytes, nuclear factor-kappa $\mathrm{B}$, in mononuclear cells of normal subjects: evidence of an antiinflammatory action. J Clin Endocrinol Metab. 2003;88(9):4496-4501.

46. Dohi Y, Ohashi M, Sugiyama M, Takase H, Sato K, Ueda R. Candesartan reduces oxidative stress and inflammation in patients with essential hypertension. Hypertens Res. 2003;26(9):691-697.

47. Koh KK, Ahn JY, Han SH, et al. Pleiotropic effects of angiotensin II receptor blocker in hypertensive patients. J Am Coll Cardiol. 2003;42(5):905-910.

48. Lauten WB, Khan QA, Rajagopalan S, et al. Usefulness of quinapril and irbesartan to improve the anti-inflammatory response of atorvastatin and aspirin in patients with coronary heart disease. Am J Cardiol 2003;91(9):1116-1119.

49. Takeda T, Hoshida S, Nishino M, Tanouchi J, Otsu K, Hori M. Relationship between effects of statins, aspirin and angiotensin II modulators on high-sensitive C-reactive protein levels. Atherosclerosis. 2003;169(1):155-158.

50. Fliser D, Buchholz K, Haller H; for the EUropean Trial on Olmesartan and Pravastatin in Inflammation and Atherosclerosis (EUTOPIA) Investigators. Antiinflammatory effects of angiotensin II subtype 1 receptor blockade in hypertensive patients with microinflammation. Circulation. 2004;110(9):1103-1107.

51. Graninger M, Reiter R, Drucker C, Minar E, Jilma B. Angiotensin receptor blockade decreases markers of vascular inflammation. J Cardiovasc Pharmacol. 2004;44(3):335-339.

52. Koh KK, Quon MJ, Han SH, et al. Additive beneficial effects of losartan combined with simvastatin in the treatment of hypercholesterolemic, hypertensive patients. Circulation. 2004;110(24):3687-3692.

53. Sardo MA, Castaldo M, Cinquegrani M, et al. Effects of AT1 receptor antagonist losartan on SICAM-1 and TNF-alpha levels in uncomplicated hypertensive patients. Angiology. 2004;55(2):195-203.

54. Schieffer B, Bunte C, Witte J, et al. Comparative effects of AT1antagonism and angiotensin converting enzyme inhibition on markers of inflammation and platelet aggregation in patients with coronary artery disease. J Am Coll Cardiol. 2004;44(2):362-368.

55. Yasunari K, Maeda K, Watanabe T, et al. Comparative effects of valsartan versus amlodipine on left ventricular mass and reactive oxygen species formation by monocytes in hypertensive patients with left ventricular hypertrophy. J Am Coll Cardiol. 2004;43(11):2116-2123.

56. Anand IS, Latini R, Florea VG; for the Val-HeFT Investigators. C-reactive protein in heart failure prognostic value and the effect of valsartan. Circulation. 2005;112(10):1428-1434.

57. Biasucci LM, Lombardi M, Piro M, Di Giannuario G, Liuzzo G, Crea F Irbesartan significantly reduces $\mathrm{C}$ reactive protein concentrations after 1 month of treatment in unstable angina. Heart. 2005;91(5):670-671.
58. Manabe S, Okura T, Watanabe S, Fukuoka T, Higaki J. Effects of angiotensin II receptor blockade with valsartan on pro-inflammatory cytokines in patients with essential hypertension. J Cardiovasc Pharmacol. 2005;46(6):735-739.

59. Miura Y, Yamamoto N, Tsunekawa S, et al. Replacement of valsartan and candesartan by telmisartan in hypertensive patients with type 2 diabetes: metabolic and antiatherogenic consequences. Diabetes Care. 2005;28(3):757-758.

60. Rosei EA, Rizzoni D, Muiesan ML; for the CENTRO (CandEsartaN on aTherosclerotic Risk factors) study investigators: Effects of candesartan cilexetil and enalapril on inflammatory markers of atherosclerosis in hypertensive patients with non-insulin-dependent diabetes mellitus. J Hypertens. 2005;23(2):435-444.

61. Ruilope LM, Malacco E, Khder Y, Kandra A, Bonner G, Heintz D. Efficacy and tolerability of combination therapy with valsartan plus hydrochlorothiazide compared with amlodipine monotherapy in hypertensive patients with other cardiovascular risk factors: the VAST study. Clin Ther. 2005;27(5):578-587.

62. Koulouris S, Symeonides P, Triantafyllou K, et al. Comparison of the effects of ramipril versus telmisartan in reducing serum levels of high-sensitivity C-reactive protein and oxidized low-density lipoprotein cholesterol in patients with type 2 diabetes mellitus. Am J Cardiol. 2005;95(11):1386-1388.

63. Schram MT, van Ittersum FJ, Spoelstra-de Man A, et al. Aggressive antihypertensive therapy based on hydrochlorothiazide, candesartan or lisinopril as initial choice in hypertensive type II diabetic individuals: effects on albumin excretion, endothelial function and inflammation in a doubleblind, randomized clinical trial. J Hum Hypertens. 2005;19(6):429-437.

64. Derosa G, Cicero AF, D'Angelo A, et al. Telmisartan and irbesartan therapy in type 2 diabetic patients treated with rosiglitazone: effects on insulin-resistance, leptin and tumor necrosis factor-alpha. Hypertens Res. 2006;29(11):849-856.

65. Link A, Lenz M, Legner D, Böhm M, Nickenig G. Telmisartan inhibits beta2-integrin MAC-1 expression in human T-lymphocytes. J Hypertens. 2006;24(9):1891-1898.

66. Nagel JM, Tietz AB, Goke B, Parhofer KG. The effect of telmisartan on glucose and lipid metabolism in nondiabetic, insulin-resistant subjects. Metabolism. 2006;55(9):1149-1154.

67. Nomura S, Shouzu A, Omoto S, Nishikawa M, Fukuhara S, Iwasaka T. Effect of valsartan on monocyte/endothelial cell activation markers and adiponectin in hypertensive patients with type 2 diabetes mellitus. Thromb Res. 2006;117(4):385-392.

68. Ogawa S, Mori T, Nako K, Kato T, Takeuchi K, Ito S. Angiotensin II type 1 receptor blockers reduce urinary oxidative stress markers in hypertensive diabetic nephropathy. Hypertension. 2006;47(4):699-705.

69. Ridker PM, Danielson E, Rifai N; for the Val-MARC Investigators. Valsartan, blood pressure reduction, and C-reactive protein: primary report of the Val-MARC trial. Hypertension. 2006;48(1):73-79.

70. Han SH, Koh KK, Quon MJ, Lee Y, Shin EK. The effects of simvastatin, losartan, and combined therapy on soluble CD40 ligand in hypercholesterolemic, hypertensive patients. Atherosclerosis. 2007;190(1):205-211.

71. Koh KK, Quon MJ, Lee Y, et al. Additive beneficial cardiovascular and metabolic effects of combination therapy with ramipril and candesartan in hypertensive patients. Eur Heart J. 2007;28(12):1440-1447.

72. Liu L, Zhao SP, Zhou HN, Li QZ, Li JX. Effect of fluvastatin and valsartan, alone and in combination, on postprandial vascular inflammation and fibrinolytic activity in patients with essential hypertension. $J$ Cardiovasc Pharmacol. 2007;50(1):50-55.

73. Rajagopalan S, Zannad F, Radauceanu A, et al. Effects of valsartan alone versus valsartan/simvastatin combination on ambulatory blood pressure, C-reactive protein, lipoproteins, and monocyte chemoattractant protein-1 in patients with hyperlipidemia and hypertension. Am J Cardiol. 2007;100(2):222-226.

74. Yano Y, Hoshide S, Ishikawa J, et al. The differential effects of angiotensin II type 1 receptor blockers on microalbuminuria in relation to low-grade inflammation in metabolic hypertensive patients. $\mathrm{Am} \mathrm{J}$ Hypertens. 2007;20(5):565-572. 
75. White M, Lepage S, Lavoie J, et al. Effects of combined candesartan and ACE inhibitors on BNP, markers of inflammation and oxidative stress, and glucose regulation in patients with symptomatic heart failure. $J$ Card Fail. 2007;13(2):86-94.

76. Willemsen JM, Westerink JW, Dallinga-Thie GM, et al. Angiotensin II type 1 receptor blockade improves hyperglycemia-induced endothelial dysfunction and reduces proinflammatory cytokine release from leukocytes. J Cardiovasc Pharmacol. 2007;49(1):6-12.

77. Galle J, Schwedhelm E, Pinnetti S; for the VIVALDI investigators. Antiproteinuric effects of angiotensin receptor blockers: telmisartan versus valsartan in hypertensive patients with type 2 diabetes mellitus and overt nephropathy. Nephrol Dial Transplant. 2008;23(10):3174-3183.

78. Nakayama S, Watada H, Mita T, et al. Comparison of effects of olmesartan and telmisartan on blood pressure and metabolic parameters in Japanese early-stage type-2 diabetics with hypertension. Hypertens Res. 2008;31(1):7-13.

79. Packard RR, Libby P. Inflammation in atherosclerosis: from vascular biology to biomarker discovery and risk prediction. Clin Chem. 2008;54(1):24-38.

80. Marchesi C, Paradis P, Schiffrin EL. Role of the renin-angiotensin system in vascular inflammation. Trends Pharmacol Sci. 2008;29(7):367-374.

81. Griendling KK, Ushio-Fukai M. Reactive oxygen species as mediators of angiotensin II signaling. Regul Pept. 2000;91(1-3):21-27.

82. Barnes PJ, Karin M. Nuclear factor-kappaB: a pivotal transcription factor in chronic inflammatory diseases. N Engl J Med. 1997;336(15): 1066-1071.

83. Förstermann U. Oxidative stress in vascular disease: causes, defense mechanisms and potential therapies. Nat Clin Pract Cardiovasc Med. 2008;5(6):338-349.

84. Ortiz MC, Manriquez MC, Romero JC, Juncos LA. Antioxidants block angiotensin II-induced increases in blood pressure and endothelin. Hypertension. 2001(3 pt2); 38:655-659.

85. Guzik TJ, Hoch NE, Brown KA, et al. Role of the T cell in the genesis of angiotensin II induced hypertension and vascular dysfunction. $J$ Exp Med. 2007;204(10):2449-2460.

86. Black S, Kushner I, Samols D. C-reactive protein. J Biol Chem. 2004;279(47):48487-48490.

87. Verma S, Szmitko PE, Ridker PM. C-reactive protein comes of age. Nat Clin Pract Cardiovasc Med. 2005;2(1):29-36.

88. Roldán V, Marín F, Lip GY, Blann AD. Soluble E-selectin in cardiovascular disease and its risk factors. A review of the literature. Thromb Haemost. 2003;90(6):1007-1020.

89. Ridker PM, Hennekens CH, Roitman-Johnson B, Stampfer MJ, Allen J. Plasma concentration of soluble intercellular adhesion molecule 1 and risks of future myocardial infarction in apparently healthy men. Lancet. 1998;351(9096):88-92.

90. Hwang SJ, Ballantyne CM, Sharrett AR, et al. Circulating adhesion molecules VCAM-1, ICAM-1, and E-selectin in carotid atherosclerosis and incident coronary heart disease cases: the Atherosclerosis Risk In Communities (ARIC) study. Circulation. 1997;96(12):4219-4225.

91. Ridker PM, Rifai N, Stampfer MJ, Hennekens CH. Plasma concentration of interleukin- 6 and the risk of future myocardial infarction among apparently healthy men. Circulation. 2000;101(15):1767-1772.
92. Ridker PM, Rifai N, Pfeffer M, Sacks F, Lepage S, Braunwald E. Elevation of tumor necrosis factor-alpha and increased risk of recurrent coronary events after myocardial infarction. Circulation. 2000;101(18): 2149-2153.

93. de Lemos JA, Morrow DA, Blazing MA, et al. Serial measurement of monocyte chemoattractant protein-1 after acute coronary syndromes: results from the A to Z trial. J Am Coll Cardiol. 2007;50(22): 2117-2124.

94. Obisesan TO, Leeuwenburgh C, Phillips T, et al. C-reactive protein genotypes affect baseline, but not exercise training-induced changes, in C-reactive protein levels. Arterioscler Thromb Vasc Biol. 2004;24(10):1874-1879.

95. Fox ER, Benjamin EJ, Sarpong DF, et al. Epidemiology, heritability, and genetic linkage of C-reactive protein in African Americans (from the Jackson Heart Study). Am J Cardiol. 2008;102(7):835-841.

96. Prasad K. C-reactive protein (CRP)-lowering agents. Cardiovasc Drug Rev. 2006;24(1):33-50.

97. Nagatomo Y, Yoshikawa T, Kohno T, et al. Effects of beta-blocker therapy on high sensitivity C-reactive protein, oxidative stress, and cardiac function in patients with congestive heart failure. J Card Fail. 2007;13(5):365-371.

98. Jenkins NP, Keevil BG, Hutchinson IV, Brooks NH. Beta-blockers are associated with lower C-reactive protein concentrations in patients with coronary artery disease. Am J Med. 2002;112(4):269-274.

99. Genser B, Grammer TB, Stojakovic T, Siekmeier R, Maerz W. Effect of HMG CoA reductase inhibitors on low-density lipoprotein cholesterol and C-reactive protein: systematic review and meta-analysis. Int J Clin Pharmacol Ther. 2008;46(October):497-510.

100. Giuseppe R, Di Castelnuovo A, Centritto F, et al. Regular consumption of dark chocolate is associated with low serum concentrations of C-reactive protein in a healthy italian population. J Nutr. 2008;138(10):1939-1945.

101. Felmeden DC, Spencer CG, Chung NA et al. Relation of thrombogenesis in systemic hypertension to angiogenesis and endothelial damage/ dysfunction (a substudy of the Anglo-Scandinavian Cardiac Outcomes Trial [ASCOT]). Am J Cardiol. 2003;92(4):400-405.

102. GISSI-HF investigators, Tavazzi L, Maggioni AP, et al. Effect of rosuvastatin in patients with chronic heart failure (the GISSI-HF trial): a randomised, double-blind, placebo-controlled trial. Lancet. 2008;372(9645):1231-1239.

103. Kastelein JJ, Akdim F, Stroes ES, et al.; for the ENHANCE Investigators. Simvastatin with or without ezetimibe in familial hypercholesterolemia. N Engl J Med. 2008;358(14):1431-1443.

104. Ridker PM, Fonseca FA, Genest J, et al; for the JUPITER Trial Study Group. Baseline characteristics of participants in the JUPITER trial, a randomized placebo-controlled primary prevention trial of statin therapy among individuals with low low-density lipoprotein cholesterol and elevated high-sensitivity C-reactive protein. Am J Cardiol. 2007;100(11):1659-1664.

105. Kinlay S. Low-density lipoprotein-dependent and -independent effects of cholesterol-lowering therapies on C-reactive protein: a metaanalysis. J Am Coll Cardiol. 2007;49(20):2003-2009. 